\title{
International Trade and Economic Misery in African Countries with Low Human Development
}

\author{
Uchechukwu C. Nwogwugwu \& Collins C. Umeghalu \\ Department of Economics, Nnamdi Azikiwe University, Awka, Anambra State, Nigeria \\ cc.umeghalu@unizik.edu.ng
}

\begin{abstract}
Puzzled by the demeaning level of poverty most African countries continue to grapple with despite their extensive participation in international trade, the study attempts to examine the encumbrances that tend to impede African countries from optimally reaping the developmental gains inherent in partaking in international trade, which seems to also worsen the economic misery the inhabitants endlessly contend with. The System Generalized Method of Moments (System-GMM) estimation technique was used in the study which involves 17 African countries and spans from 1995 - 2018. While misery index is used to measure economic misery, the impact of international trade on economic misery is captured by means of its effect via economic misery, economic growth rate, balance of payment, total export, manufacture export and exchange rate. The results of the study reveal that balance of payments, total export, manufacture export, per capita GDP growth rate, exchange rate and lagged form of economic misery all have positive effect on economic misery. While the effects of total export, manufacture export, per capita GDP growth rate, and exchange rate on economic misery are significant, those of balance of payments and lagged form of economic misery are insignificant. While the study recommends that international trade be engaged strategically such that it results in favorable balance of payments, it also encourages the discarding of obsolete trade policies such as outright bans on importation of certain commodities. Bilateral trade agreements are recommended over multilateral trade agreements, since they are more mutually beneficial and binding on the parties involved.
\end{abstract}

Keywords: International trade, Development, Economic misery, Africa

JEL Classification: F10, I31, I32, O55

\section{How to Cite:}

Nwogwugwu, U. C., and Umeghalu, C. C. (2021). International trade and economic misery in African countries with low human development. International Journal of Finance Research, 2(4). 212 - 243. DOI: https://doi.org/10.47747/ijfr.v2i4.446

\section{Introduction}

The notion that international trade brings about economic gains is seldom disputed. It is this gain that some trade theories refer to when they describe the disposition of countries who engage in international trade as being 'better off.' Interestingly, the gains that come with engaging in international trade have never been suggested by any trade theory as being distributed equitably between or among the trading countries. Thus, it could be argued that while international trade makes some countries better off, it tends to make some others worse off or maybe not as better off as the other country. That a country becomes worse off by 
engaging in trade with other countries may sound incredible, but a closer look at the growth and development indicators of some countries could fizzle out any doubt (Thirlwall, 2000).

The purported inability of international trade to bring about economic growth and development in some countries might stem from the difficulty involved in exporting goods to some countries; it could also be the manner in which these transactions are carried out. These connote the existence of protectionism tendencies which are exhibited through tariff and nontariff barriers or outright ban of certain commodities. Other factors that could serve as impediments for international trade to amount to economic growth and development could also include the existence or absence of bilateral and/ or multilateral trade agreements, low productive capacity or the inability to decipher that increase in international trade does not necessarily amount to increase in export, which informs a country on how to effectively determine the outcome of trade such that it nudges it on the path of economic development.

Having export goods which largely comprise of primary goods suggests that the export earnings of many African countries are irregular, since they are more vulnerable to the vagaries of the international market. Furthermore, these goods also have very low income and price elasticities, implying that increases in income of consumers or decreases in prices of the export commodities rarely bring about increases in their demand. However, decreases in the prices of these commodities bring about decreases in the earnings of government and individuals whose sources of livelihood depend on the export of these commodities, with their attendant impact on the standard of living of the citizenry (Ezenekwe, Umeghalu \& Uzodigwe, 2018).

Another trait exhibited by these countries that is occasioned by their heavy reliance on one or two primary commodities is the "Dutch Disease Syndrome." The Dutch disease model explains the causal relationship between the increase in economic activity of a specific sector, (usually the exploitation of natural resources) and the decline in economic activities in the other sectors (usually the manufacturing and agricultural sectors). They are of the position that it results from the revenue increases in the growing sector which leads to the appreciation of the domestic currency which then makes export commodities of the other sectors to become more expensive and inadvertently less competitive (Corden, 1984).

It is in attempts to sort out some of the afore mentioned factors that supposedly hinder developing countries from reaping optimal benefits inherent in international trade and more specifically the perceived trade barriers among African countries that the African Continental Free Trade Area (AfCFTA) was conceptualized. AfCFTA is the African Continent's ambitious integration initiative embedded in the African Union's Agenda 2063. AfCFTA's main objective is to create a single continental market for goods and services with free movement of people and investments, thus expanding intra-African trade across the continent, enhancing competitiveness and supporting economic transformation in Africa. The AfCFTA is expected to increase intra-Africa trade from an existing level of about $13 \%$ to $25 \%$ or more through better harmonization and coordination of trade liberalization (European Union, 2019). Interestingly, international trades between African countries and the rest of the world have peculiar trends. Africa's share of global trade put at $2.4 \%$ as at 2015 , this tends to be too negligible for a continent with about $20 \%$ of the world's population, even though it accounts for only $3 \%$ of the global GDP. Furthermore, a substantial percentage of the commodities exported by African countries are primary commodities while the volume of trade amongst African countries is astonishingly low, put at 14\% as at 2018 (Verter, 2017; Coleman, 2020). 
Most African countries have countries outside their continent as their largest trading partners, an occurrence that is inconsistent to the 'gravity trade theory.' Table 1 below shows select African countries with their largest trading partners and the value of trade with these partners as a proportion of total trade.

Establishing a Free Trade Area (FTA) is not far from being a laudable initiative, but is it capable of improving the living standard of the citizenry of participating countries? Highlighting the disparity between a free trade area and a free trade zone stands to give an idea of what AfCFTA portends for the member countries. A free trade area is a region in which a group of countries have signed a free trade agreement and maintains little or no barriers to trade in the form of tariffs or quotas among each other. On the other hand, a free trade zone is a designated location in a geographical area where enterprises can operate without trade barriers, bureaucratic bottlenecks and custom interference in order to attract new businesses and foreign participation. It is an industrial trade promotion instrument established to help reduce unemployment and generate foreign exchange earnings, and serves as engines for industrialization and economic growth by attracting foreign direct investments. From the foregoing, establishing a free trade area implies people and goods having unhindered access to the markets of member states, marginal increase in trade among members and total or partial removal of tariffs, quotas and other barriers to international trade. On the other hand, it also implies reduction in revenue accruals from import duties and related taxes on import and export goods.

Table 1: The Main import and export partners of select African countries.

\begin{tabular}{|c|c|c|}
\hline Country & $\begin{array}{ll}\text { Largest } & \text { Import } \\
\text { Partner }(\%) & \end{array}$ & Largest Export Partner (\%) \\
\hline Nigeria & China $(28 \%)$ & India $(18 \%)$ \\
\hline Cameroon & China $(19 \%)$ & Netherlands $(15.6 \%)$ \\
\hline Ghana & China $(16.8 \%)$ & India $(23.8 \%)$ \\
\hline South Africa & China $(18.0 \%)$ & China $(9.9 \%)$ \\
\hline Egypt & China $(7.9 \%)$ & United Arab Emirates (10.9\%) \\
\hline Kenya & China $(22.5 \%)$ & Uganda (10.8\%) \\
\hline Ethiopia & China $(24.1 \%)$ & Sudan $(23.3 \%)$ \\
\hline Senegal & France $(16.3 \%)$ & Mali $(14.8 \%)$ \\
\hline Uganda & China $(17.4 \%)$ & Kenya $(17.7 \%)$ \\
\hline Angola & Portugal (17.8\%) & China $(61.2 \%)$ \\
\hline
\end{tabular}

Source: CIA World Factbook, 2019

With the major goal of partially or utterly removing trade barriers in an effort to increase the volume of trade amongst African countries, the AfCFTA initiative might not be the much sought after restorative policy that would ameliorate Africa's development challenges through international trade. This is partly because primary commodities have low price and income elasticities, and since more than 50 percent of the total exports of most African countries are comprised of primary goods, the AfCFTA initiative will most likely bring about only a little increase in total export. This will invariably stimulate only a marginal increase in economic growth and development, unless the initiative is accompanied with efforts directed towards 
diversifying the goods the export baskets of the participating countries are comprised of and improving the stability of the exchange rates of the participating countries.

The relatively low trade volume among African countries is not necessarily due to the existence of tariff and non-tariff trade barriers alone. The low productive capacities and poor quality of goods produced by many African countries which are directly or indirectly traceable to lack of social infrastructure, low technical know-how and poor entrepreneurial ability are also sources of concern. Aside from being largely unable to compete effectively with products manufactured in technologically more advanced countries in terms of quality and price, a considerable proportion of commodities produced in Africa are manufactured by producers who operate in the informal sector of these economies. Hence, many of their activities are carried out through crude methods, in obscurity and by persons who just want to get by, instead of having the ambition of becoming notable global players. Table 1 shows that most African countries have China as the country from which most of their imports come from and there is no sufficient evidence that trade barrier is the reason for such occurrences.

The perception that the potential gain derivable from the external sector of an economy and the attendant improvement in the economic development of a country accrues only through its impact on economic growth does not seem utterly true. The proceeds of international transactions tend to have direct bearings on economic development. Balance of payments over time determines the exchange rate value of a country's currency which in turn affects the rate of inflation and the purchasing power of its currency. A country's balance of trade largely determines its balance of payments since it accounts for a substantial proportion of a countries total economic activity. The balance of payments of a country affects its exchange rate; furthermore, exchange fluctuations affect the purchasing power of a country's currency which to a large extent affects the standard of living of the citizenry. While an increase in purchasing power due to the appreciation of domestic currency could improve standard of living, a decrease in purchasing power due to the depreciation of domestic currency could in a similar vein exacerbate economic misery.

It has been argued that international trade is an important catalyst of economic development, however, the suspicion that it has not engendered economic growth and development in some climes makes it a puzzle that has aroused the interest of a number of scholars. Studies have shown that the importance of international trade to every economy is enormous; it does not only afford the citizens of a country means of livelihood, it also provides foreign exchange earnings for countries and empowers them to effectively manage their monetary and fiscal positions effectively. International trade holds the potentials of bringing about improvement in the living standard of the average man, especially those who are directly or indirectly employed in industries and sectors that produce export goods or deal on imported goods (Kalaitzi \& Chamberlain, 2020; Oreiro \& Silva, 2019; Zahonogo, 2016).

Notwithstanding the fact that most African countries actively engage in international trade for decades, a majority of its populace continue to grapple with poverty in its most debilitating level. Seychelles is the only African country that is ranked among countries with very high Human Development Index (HDI). While only Libya, South Africa, Gabon, Egypt, Botswana, Tunisia, Algeria and Mauritius are ranked as having high HDI, other African countries belong to the categories of countries with low and medium HDI (See Table 2). If Africa's trade with the rest of the world has not brought about visible improvement in their economic development, is it the improved trade relations amongst just African countries that will do so? 
Vol 2 No. 4, December 2021

Table 2. Human Development Index (HDI) and Manufacture Export as a proportion of Merchandise Export in Selected African Countries

\begin{tabular}{|c|c|c|c|c|c|c|c|}
\hline Country & Year & 1995 & 2000 & 2005 & 2010 & 2015 & 2018 \\
\hline \multirow[t]{2}{*}{ Nigeria } & HDI & 0.432 & 0.445 & 0.466 & 0.482 & 0.520 & 0.534 \\
\hline & $\begin{array}{l}\text { MFX as \% MD } \\
\text { Exp }\end{array}$ & 1.002161 & 0.206996 & 1.768423 & 6.685777 & 3.382166 & \\
\hline \multirow[t]{2}{*}{ Cameroon } & HDI & 0.442 & 0.438 & 0.455 & 0.471 & 0.548 & 0.563 \\
\hline & $\begin{array}{l}\text { MFX as \% MD } \\
\text { Exp }\end{array}$ & 7.917894 & 3.26108 & 2.840368 & 7.536951 & 8.90384 & \\
\hline \multirow[t]{2}{*}{ Cote d'Ivoire } & HDI & 0.399 & 0.407 & 0.431 & 0.454 & 0.494 & 0.516 \\
\hline & $\begin{array}{l}\text { MFX as \% MD } \\
\text { Exp }\end{array}$ & 6.568391 & 14.47951 & 18.71063 & 16.17189 & 8.106354 & \\
\hline \multirow[t]{2}{*}{ Ghana } & HDI & 0.469 & 0.483 & 0.519 & 0.554 & 0.585 & 0.596 \\
\hline & $\begin{array}{l}\text { MFX as \% MD } \\
\text { Exp }\end{array}$ & 13.16826 & 14.62174 & 32.52972 & 20.68046 & 15.71943 & \\
\hline \multirow[t]{2}{*}{ Morocco } & HDI & 0.500 & 0.531 & 0.575 & 0.618 & 0.660 & 0.676 \\
\hline & $\begin{array}{l}\text { MFX as \% MD } \\
\text { Exp }\end{array}$ & 51.40239 & 64.09312 & 65.79775 & 66.32246 & 69.41845 & \\
\hline \multirow{2}{*}{ Zambia } & HDI & 0.426 & 0.438 & 0.480 & 0.531 & 0.570 & 0.591 \\
\hline & $\begin{array}{l}\text { MFX as \% MD } \\
\text { Exp }\end{array}$ & 6.95219 & 10.73806 & 8.764034 & 6.287581 & 10.05394 & \\
\hline \multirow[t]{2}{*}{ Uganda } & HDI & 0.354 & 0.395 & 0.442 & 0.489 & 0.515 & 0.528 \\
\hline & $\begin{array}{l}\text { MFX as \% MD } \\
\text { Exp }\end{array}$ & 4.390541 & 3.108751 & 11.53509 & 22.84898 & 24.63931 & \\
\hline \multirow[t]{2}{*}{ Malawi } & HDI & 0.333 & 0.362 & 0.400 & 0.437 & 0.475 & 0.485 \\
\hline & $\begin{array}{l}\text { MFX as \% MD } \\
\text { Exp }\end{array}$ & 7.344854 & 7.446085 & 16.27378 & 8.958683 & 15.35641 & \\
\hline \multirow[t]{2}{*}{ Kenya } & HDI & 0.457 & 0.446 & 0.490 & 0.533 & 0.562 & 0.579 \\
\hline & $\begin{array}{l}\text { MFX as \% MD } \\
\text { Exp }\end{array}$ & 27.57109 & 20.77722 & 31.90692 & 34.66569 & 37.88727 & \\
\hline \multirow[t]{2}{*}{ Rwanda } & HDI & 0.291 & 0.337 & 0.413 & 0.488 & 0.515 & 0.536 \\
\hline & $\begin{array}{l}\text { MFX as \% MD } \\
\operatorname{Exp}\end{array}$ & 12.13915 & 2.738639 & 3.557374 & 8.450775 & 15.44185 & \\
\hline \multirow[t]{2}{*}{ Ethiopia } & HDI & 0. & 0.283 & 0.348 & 0.412 & 0.453 & 0.470 \\
\hline & $\begin{array}{l}\text { MFX as \% MD } \\
\text { Exp }\end{array}$ & 11.17065 & 9.777657 & 4.58148 & 8.906119 & 7.330661 & \\
\hline \multirow[t]{2}{*}{ Zimbabwe } & HDI & 0.475 & 0.452 & 0.462 & 0.472 & 0.543 & 0.563 \\
\hline & $\begin{array}{l}\text { MFX as \% MD } \\
\operatorname{Exp}\end{array}$ & 37.11155 & 26.90844 & 38.09668 & 36.42387 & 16.78748 & \\
\hline \multirow[t]{2}{*}{ Tanzania } & HDI & 0.384 & 0.395 & 0.441 & 0.487 & 0.519 & 0.528 \\
\hline & $\begin{array}{l}\text { MFX as \% MD } \\
\operatorname{Exp}\end{array}$ & 16.84617 & 19.63217 & 14.03759 & 24.06316 & 26.09708 & \\
\hline \multirow[t]{2}{*}{ Senegal } & HDI & 0.384 & 0.390 & 0.429 & 0.468 & 0.504 & 0.514 \\
\hline & $\begin{array}{l}\text { MFX as \% MD } \\
\text { Exp }\end{array}$ & 48.13864 & 26.93586 & 43.42338 & 41.66855 & 31.8136 & \\
\hline \multirow{2}{*}{$\begin{array}{l}\text { Congo } \\
\text { Republic }\end{array}$} & HDI & 0.355 & 0.333 & 0.375 & 0.416 & 0.445 & 0.459 \\
\hline & $\begin{array}{l}\text { MFX as \% MD } \\
\text { Exp }\end{array}$ & 2.70953 & & & 30.47747 & & \\
\hline \multirow[t]{2}{*}{ Mozambique } & HDI & 0.259 & 0.301 & 0.349 & 0.396 & 0.428 & 0.446 \\
\hline & $\begin{array}{l}\text { MFX as \% MD } \\
\text { Exp }\end{array}$ & 13.39136 & 6.66755 & 6.504783 & 1.974486 & 8.417639 & \\
\hline \multirow{2}{*}{$\begin{array}{l}\text { Central } \\
\text { African } \\
\text { Republic }\end{array}$} & HDI & 0.330 & 0.325 & 0.345 & 0.365 & 0.375 & 0.395 \\
\hline & $\begin{array}{l}\text { MFX as \% MD } \\
\text { Exp }\end{array}$ & 44.76777 & 68.24544 & 37.81693 & 3.154932 & 76.13562 & \\
\hline
\end{tabular}

Source: World Development Indicators, 2019. 
Studies have shown that international trade spurs economic growth and development, that it has not been the case for many African countries should suggest that a country does not become better off by merely engaging in international trade, it rather does if international trade is carried out strategically; what then does carrying out international trade strategically entail?

Asking why countries that engage in international trade continue to grapple with poverty gives the impression that international trade is about the only factor that instigates growth and development. Interestingly, studies have shown that trade is indeed one of the major factors driving national average incomes (GDP per capita) and macroeconomic productivity (GDP per worker) over the long-run; more specifically, as at the $1870 \mathrm{~s}$, the sum of worldwide exports accounted for less than $10 \%$ of global output, while it got close to about $25 \%$ in recent years. This indicates a more than proportional growth in global trade in about a century (Ortiz-Ospina, Beltekian, \& Roser, 2018). The international trade structure and the composition of export goods of many African countries somewhat give a glimpse of why the continent's involvement in international trade has not ameliorated its economic development challenges. Many countries in Africa rely on very few export commodities which are in most cases primary commodities usually exported with little or no value addition (Lopez, 2017; Oreiro \& Silva, 2019).

A substantial proportion of the goods exported by most African countries are of the primary sector extraction; manufacture export is relatively very low. The manufacturing sectors of most African economies continue to wallow in endless struggle in their efforts to effectively compete with rival firms outside the continent in the international market. This scenario has been attributed to the existing poor infrastructures and acute shortage of skilled manpower in these countries. However, these reasons do not explain why some industries that used to function effectively are now moribund, nor do they clarify why Africa's manufacture export as a percentage of global manufacture export is not only negligible but has plummeted over the years (World Bank, 2019). Manufacture exports play important roles in making international trade and the external sector in its entirety bring about economic development. While primary commodities largely have very low price and income elasticities, manufacture commodities on the other hand have high price and income elasticities, indicating that decrease in price is usually followed by increase in demand while increase in income also spurs increase in demand.

The above observed disparity between primary product export and manufacture export hints that the African Continental Free Trade Area (AfCFTA) initiative might not be the panacea desired in the efforts to make international trade more development oriented in Africa, since the AfCFTA initiative is just an aspect of a broader development plan, the African Union's 'Agenda 2063'. The highlighted difference also comes very close to providing convincing explanation to the low economic development impact of international trade in Africa, and in that light tends to deliver the narrative of the process that leads to the emergence of the Dutch disease, particularly how it arm-twists a potentially development spurring process into being the opposite. However, it has been observed that Dutch disease does not result from unfavourable trade outcomes alone; studies have shown that foreign investments, remittances and foreign aids also bring about the Dutch disease (Fielding \& Gibson, 2011; Andrade and Duarte, 2017; Lopez, 2017). Instructively, all the economic variables that studies have shown to bring about the Dutch disease do so through the impact they exert on the exchange rate. However, while Dutch disease is said to bring about appreciation of the exchange rate, 
available data show that African countries exhibit the very opposite (See Table3 ). This depicts that unfavaourable trade balances and unhealthy balance of payments might 'also be part of the reasons why international trade drags in enhancing economic development in Africa, and not just Dutch disease, due to their effects on the exchange rate (World Bank, 2019).

Table 3. Current Account Balance and Official Exchange Rate of Selected African Countries

\begin{tabular}{|c|c|c|c|c|c|c|c|}
\hline Country & Year & 1995 & 2000 & 2005 & 2010 & 2015 & 2018 \\
\hline \multirow[t]{2}{*}{ Nigeria } & Exchange Rate & 21.9 & 101.7 & 131.3 & 150.3 & 192.4 & 306.1 \\
\hline & BoP (\$ bls) & -2.578 & 7.427 & 36.529 & 13.111 & -15.763 & 8.499 \\
\hline \multirow[t]{2}{*}{ Cameroon } & Exchange Rate & 499.1 & 712.0 & 527.5 & 495.3 & 591.5 & 555.7 \\
\hline & BoP (\$ bls) & -0.09 & -0.333 & -0.565 & -0.650 & -1.174 & -1.555 \\
\hline \multirow[t]{2}{*}{ Cote d'Ivoire } & Exchange Rate & 499.1 & 712.0 & 527.5 & 495.3 & 591.5 & 555.7 \\
\hline & BoP (\$ bls) & -0.492 & -0.241 & 0.04 & 0.465 & -0.201 & -1.459 \\
\hline \multirow[t]{2}{*}{ Ghana } & Exchange Rate & 0.1 & 0.5 & 0.9 & 01.4 & 3.7 & 4.6 \\
\hline & BoP (\$ bls) & -0.32 & -0.483 & -1.219 & -2.770 & -2.836 & -2.075 \\
\hline \multirow[t]{2}{*}{ Morocco } & Exchange Rate & 8.5 & 10.6 & 8.9 & 8.4 & 9.8 & 10.7 \\
\hline & BoP (\$ bls) & -1.186 & 1.434 & -0.101 & -4.078 & -2.165 & -5.317 \\
\hline \multirow[t]{2}{*}{ Zambia } & Exchange Rate & 0.9 & 3.1 & 4.5 & 4.8 & 8.6 & 10.5 \\
\hline & BoP (\$ bls) & -0.145 & -0.438 & -0.232 & -1.525 & -0.831 & -1.260 \\
\hline \multirow[t]{2}{*}{ Uganda } & Exchange Rate & 969.0 & 1644.5 & 1780.5 & 2177.6 & 3240.7 & 3727.1 \\
\hline & BoP (\$ bls) & -0.281 & -0.359 & 0.049 & -1.610 & 1.675 & -1.913 \\
\hline \multirow[t]{2}{*}{ Malawi } & Exchange Rate & 15.3 & 59.5 & 118.4 & 150.5 & 499.6 & 732.3 \\
\hline & BoP (\$ bls) & -0.078 & -0.073 & -0.486 & -0.597 & -0.572 & -0.638 \\
\hline \multirow[t]{2}{*}{ Kenya } & Exchange Rate & 51.4 & 76.2 & 75.6 & 79.2 & 98.18 & 101.30 \\
\hline & BoP (\$ bls) & -0.283 & -0.199 & -0.275 & -2.369 & -4.289 & -4.801 \\
\hline \multirow[t]{2}{*}{ Rwanda } & Exchange Rate & 262.2 & 389.7 & 557.8 & 583.1 & 721.0 & 861.09 \\
\hline & BoP (\$ bls) & 0.057 & -0.094 & -0.065 & -0.414 & -1.106 & -0.738 \\
\hline \multirow[t]{2}{*}{ Ethiopia } & Exchange Rate & 6.2 & 8.2 & 8.7 & 14.4 & 20.6 & 27.43 \\
\hline & BoP (\$ bls) & 0.039 & 0.013 & -1.568 & -0.425 & -6.579 & -5.253 \\
\hline \multirow[t]{2}{*}{ Zimbabwe } & Exchange Rate & 0.01 & 0.04 & 22.4 & 1 & 1 & 1 \\
\hline & BoP (\$ bls) & -0.369 & 0.322 & -0.087 & -1.444 & -1.521 & -1.035 \\
\hline \multirow[t]{2}{*}{ Tanzania } & Exchange Rate & 574.8 & 800.4 & 1128.9 & 1395.6 & 1991.4 & 2263.8 \\
\hline & BoP (\$ bls) & -0.59 & -0.472 & -0.938 & -2.385 & -3.846 & -2.141 \\
\hline \multirow[t]{2}{*}{ Senegal } & Exchange Rate & 499.1 & 712.0 & 527.5 & 495.3 & 591.5 & 555.7 \\
\hline & BoP (\$ bls) & -0.323 & -0.328 & -0.678 & -0.568 & -1.004 & -1.731 \\
\hline \multirow{2}{*}{$\begin{array}{l}\text { Congo } \\
\text { Republic }\end{array}$} & Exchange Rate & 499.1 & 712.0 & 527.5 & 495.3 & 591.5 & 555.7 \\
\hline & BoP (\$ bls) & 0.015 & 0.086 & -0.389 & -2.174 & -1.433 & -0.208 \\
\hline \multirow[t]{2}{*}{ Mozambique } & Exchange Rate & 9.0 & 15.2 & 23.0 & 34.0 & 47.0 & 61.6 \\
\hline & BoP (\$ bls) & -0.464 & -0.697 & -0.761 & -1.679 & -5.968 & -4.96 \\
\hline
\end{tabular}

Source: World Development Indicators, 2019

Regardless of the existence of Dutch disease or not, the structural dispositions of many African countries suggest that they are inclined to be infected by Dutch disease, if they are not already infected. Only Senegal, South Africa, Egypt, Morocco and a few other African countries have total manufacture exports as percentage of total merchandise export of 40 per cent and above. Most African countries have revenue proceeds from export of primary commodities that consist of more than 50 percent of government's total revenue, while only a 
handful of these countries have tax revenues as percentages of total government revenues of more 50 per cent. The existence of Dutch disease or export earnings that are fraught with fluctuations due to the volatility that characterize commodity prices in the international market clearly indicates that African countries do not strategically engage in international trade in manners that spur economic development or mitigate economic misery (World Bank, 2018).

Dutch disease tends to share a very close relationship with "vicious circle of poverty." While Dutch disease seems to be the modus through which the circle of misery comes to fruition, the 'vicious circle of poverty' seems to perpetuate it. Put succinctly, international trade either improves economic development or exacerbates poverty. When balance of trade is favourable, more opportunities are created and the economy experiences the stability that engenders economic growth and development. Favourable balance of payments afford a country the opportunity to increase real income by increasing nominal income, and the leverage to diversify the economy since certain industries can thrive only under specified minimum average income and sustainable policies.

The study broadly attempts to determine if international trade undermines economic development efforts in Africa. This objective is premised on the view that many African economies are besieged by or wont to be susceptible to the Dutch disease, since the massive export of one or two primary commodities supposedly brings about drastic appreciation of the domestic currency which then makes manufacture exports of the countries in question to become less competitive in the international market. More specifically, the study seeks to evaluate the impact of international trade on economic development in Africa, taking into consideration the contribution of manufacture export, balance of payments and exchange rate in this regard. It promises to bring to the fore how international trade has fared in contributing towards economic development in Africa, the potentials it holds in this respect as posited by Friedrich List (1789 - 1846) in his 'National Economics' theory and the need for bilateral and multilateral trade agreements.

The study covers the period between 1995 - 2018, a time interval within which the economies of most African countries cannot be said to still have sectors that largely follow protocols established during colonial rule or still grapple with the over bearing influence of external forces. It involves 17 African countries which exhibit at least one of the three cardinal effects of Dutch disease and have low manufacture exports; they are selected from all the regions in Africa. More specifically, the select countries have the following features: (i) They have more than 50 per cent of their export earnings sourced from the export of one or two primary commodities. (ii) The value of their manufacture export as percentage of the value of total export is less than 25 per cent. (iii) They have average HDI of 5.5 or less over the period of the study.

\section{Are African countries plagued by the "Dutch Disease?"}

"Dutch disease" could simply be described as the reduction in a country's export performance as a result of appreciation of its exchange rate traceable to the discovery of a natural resource such as oil. Dutch disease is believed to be a scourge that is common among resource rich countries. It has its origin from the Netherland's experience following the country's discovery and exploitation of vast natural gas reserves in the 1960s. This led to the concentration of economic activities in the gas industry, leading to massive production and exportation of gas 
and attendant appreciation in the value of the country's currency and increase in the prices of non-tradable goods and services, thereby hurting the export of most tradable goods (Corden \& Neary, 1982).

From the literature, the evidence of the existence of Dutch disease in a particular country is categorized into three cardinal effects: the resource movement effect, the spending effect, and the exchange rate effect. The resource movement effect stems from the supply side of the economy wherein the booming natural resource sector attracts productive resources from the other sectors, which results in the decrease of the productive capacity and output of these other sectors. On the other hand, the spending effect occurs on the demand side of the economy; it results from the excessive revenue accruals from the natural resource sector. This leads to increased income, which invariably brings about sharp increase in demand for goods in the other sectors of the economy, and thus instigating rise in the rate of inflation. This makes export goods from the other sectors less competitive in the international market. The exchange rate effect results from the huge foreign exchange inflow derived from natural resource export. And with the increase in foreign exchange inflow comes increase in the demand of the domestic currency of the natural resource rich country, which brings about appreciable appreciation in the value of the domestic currency and thereby making tradable goods relatively more expensive and less competitive both domestically and in the international market (Corden, 1984).

The intricacies of economic activities that could lead a country to be plagued by the Dutch disease could initially and partly emanate from the outcome of its international trade on natural resources; this indicates that there are other economic factors that could spur economic anomalies with symptoms like those exuded by a Dutch disease infected country. The unhealthy impact of natural resources sales in the international market on an economy that brings about Dutch disease occurs via its effect on exchange rate. In that light, other economic activities that could bring about appreciable increase in the exchange rate value of a country like increase in foreign investment, foreign aid and remittances could also bring about economic conditions similar to those of Dutch disease. Consequently, since Dutch disease is largely an exchange rate issue, it could also be caused by other factors that could instigate sharp increases in the exchange rate value of a country (Rajan \& Subramanian, 2009; Acosta \& Mandelman, 2009)

Studies have shown that foreign aid affects the growth of the manufacturing sector. Aid flows is believed to have systematic adverse effect on a country's competitiveness as reflected in the lower relative growth rate of exportable industry goods of 47 significant aid receiving low income countries in the study carried out by Rajan and Subramanian (2009). The work of Fielding and Gibson (2011) in which they found that aid inflow causes a real exchange rate appreciation in many aids receiving countries also corroborates this view. Remittances are also believed to cause Dutch disease. Acosta and Mandelman (2009) found that an increase in remittances flows lead to a decline in labour supply and an increase in consumption demand that is biased towards non-tradables, since higher non-tradable prices serve as incentives for expansion of that sector, culminating into reallocation of labour away from the tradable sector. The work of Eromenko (2016) also supports this view. In his study wherein he tested whether the large inflow of foreign exchange coming into Kyrgyzstan and Tajikistan from labour migrants does cause Dutch disease. He was able to trace evidence of deindustrialization to the strong appreciation of their local currencies during high oil prices, indicating transfer of Dutch disease from resource rich Russia. 
Even though it is not popular among scholars, foreign investment is also considered as one of the means through which a country could contract the Dutch disease. Botta, Godin and Missaglia (2015) tried to establish that there is a relationship between FDI in Columbia's mining sector and exchange rate appreciation in the country, indicating that FDI inflows could spur the manifestation of Dutch disease. The study of Lartey (2007) also corroborates the view of the trio above. Lartey (2007) tried to investigate the question of whether capital inflows, particularly FDI cause the real exchange rate to appreciate. The results of the study show that FDI causes real exchange rate to appreciate.

Interestingly, there are economies that could be described as being besieged by the Dutch disease but exhibit only two out of three major traits associated with the Dutch disease. More specifically, there are a number of countries, mostly low income countries that exhibit the resource movement and spending effects of the Dutch disease while the exchange rate effect is manifested in a reverse order. This implies that instead of the noticeable appreciation of the domestic currency that comes with the huge foreign exchange earnings accrued from the export of natural resources, the domestic currencies of these countries continue to depreciate over time. This could be attributed to the high level of dependence of these economies on import goods and high cost of governance which occasions the extreme manifestation of the spending effect of the Dutch disease and increases demand for foreign exchange to finance the huge increase in demand for imports goods. Also, their low income disposition prompts increment in minimum wage by the government, another means through which the spending effect is made manifest; such increments are usually followed with drastic falls in the value of the domestic currency. Table 3 shows the trend of balance of payments and exchange rate values of designated countries (World Development Indicators, 2019).

There are also countries that the exchange rate values of their domestic currencies neither appreciate nor depreciate in tandem with inflow of foreign exchange, even though they exhibit the resource movement and spending effects of the Dutch disease; they do not exhibit the exchange rate effect at all. This could be because they either have fixed exchange rates or have currencies that are used by several countries or/ and have currencies that are pegged to other currencies.

From the foregoing, it could be deduced that Dutch disease and its economic development implications are not likely to be neutralized by merely expanding international trade or banning importation of some import goods, it could rather be put at bay through surgical policies that are directed towards diversifying and increasing export while allowing for import to the extent that is favourable for the economy. That is, participating in international trade in manners that allow the exchange rate of a country's domestic currency to remain stable. Interestingly, most countries of the world, low income and high income countries alike have the Dutch disease lurking in the shadows of their economies, and would be made manifest if the requisite policies and checks are not put in place to put it at bay consistently.

\section{Does Free Trade Make all International Trade Participating Countries Better-off?}

When countries that actively engage in international trade continue to grapple with extreme poverty one cannot help but wonder if these international transactions make them better off or not. Existing international trade theories mentioned the existence of a number of disparities between trading countries including cost of production, technology, natural resources and factor endowments among others as factors believed to prompt international trade between countries. Interestingly, these views seem to have stemmed from the assumption that 
international trade is largely about making international sales and purchases in the most prudent fashion, which is a narrow perspective from which to see international trade. Beyond the afore stated differences, international trade has bearing on the general performance of the economy of a country with its attendant effect on the wellbeing of the citizenry. In that light, informed policy makers, especially in countries with very high living standards try to influence trade between their countries and others countries such that the outcomes are not inimical to the wellbeing of the populace, using tariff and non-tariff barriers.

Unfavourable terms of trade put the exchange rate of a country under pressure, as the shortage of foreign exchange needed to finance imports in a country compels its monetary regulatory agency to devalue its currency as a means of easing the pressure. From another dimension, the humongous export of just one or two primary commodities as is the case in many low income countries could result in the over appreciation of a country's currency, spurring drastic decrease in the export of other commodities, especially secondary goods; the 'Dutch disease' syndrome. An ill performing economy structurally skewed to perpetually underperform could be occasioned by unfavourable trade outcomes or the Dutch disease syndrome; this closely describes the economies of many African countries (Kalaitzi \& Chamberlain, 2020).

Many of the trade theories, especially the earlier ones, are of the view that countries are better off when they import from countries with advantages in the production of certain goods due to lower cost of production, technology and natural resources among others. However, these theories omit to state clearly what becomes of countries whose productions are not considered advantageous in any way (Thirlwind, 2000). Let us assume that the production of some commodities in country A come with certain advantages over another country B, which is inclined to import from country A. However, there are also these other countries $\mathrm{C}$ and $\mathrm{D}$ with the same advantage as country A over country B in the production of the said commodity, albeit with a pact with country B. The agreement stipulates country B to import the said products from countries $\mathrm{C}$ and $\mathrm{D}$ with the understanding that it would be allowed to export to these countries the commodities they are disadvantaged in their production.

Two facts could be deduced from the conjecture above. Firstly, a country does not become better off by simply engaging in international trade, it becomes better off when it engages in international trade strategically. That is, international trade should be performed with sagacity and understanding of how to effectively regulate the various related economic activities and ripple effects that result from the transactions, such that it ensures that the country becomes better off. Secondly, international trade is comprised of importation and exportation; increase in import and exports do not bring about similar impact in an economy. Hence, initiating policies that will improve international trade does not necessarily amount to increase in export or import. Therefore, knowing which between the duo of import and export, depending on which better serves a country's interest at a particular time, should inform a country of the right policies that will prod its economy on the path of sustainable development.

Exports goods could be categorized into two; primary commodities and manufactures. While primary commodities are exploited natural resources and agricultural products which tend to have little or no value addition before they are exported, manufactures are processed and packaged goods. The percentages of primary goods and manufactures exported as proportions of total export determine a great deal whether a country's participation in international trade could amount to improved welfare for its populace. The primary sector consists of fewer skilled workers, numerous unskilled workers, and the peasant farmers. Export goods of the 
primary sector extraction have very low or zero price and/ or income elasticity. This indicates that countries that their exports are largely comprised of primary goods are exposed to the adverse effects of the volatile international market, wherein increases or decreases in their prices or in income levels largely do not instigate anticipated changes in quantity demanded. In that light, countries whose total exports are largely comprised of primary goods are more likely to have their economies exposed to the vagaries of international market and their economic performance inevitably affected by exchange rate and government revenue volatilities that come with it (Kalaitzi \& Chamberlain, 2020).

Conversely, manufactures are price and income elastic; this indicates that countries that heavily rely on them for export do not risk huge unhealthy economic exposure. Increases and decreases in the average price of manufactures and their substitutes often bring about decreases and increases in the quantity demanded, offsetting impending economic jerk that could alter anticipated improved economic performance. Developing nations have export compositions that have large proportions of primary commodities while the high income countries have export compositions that largely consist of sizeable proportions of manufactures. In that order, one would have imagined the high income countries would export manufactures to the low income countries while importing their primary products, but it is not often the case. It is rarely the case only when the crops are not grown at all or sufficiently grown in the developed countries, and often occurs under a bilateral agreement when they do.

Protectionist policies are used by governments of many developing and developed countries alike to give advantage to local producers of commodities imported from other countries. The governments of some developing countries have taken a cue from this line of action, and have even gone further to institute bans on the importation of certain goods they consider hazardous to local industries. These clearly imply that international trade makes participating countries better off only when it is done strategically within certain safe zones or if certain conditions are met.

\section{How free is International Free Trade?}

There is a semblance of consensus that international trade spurs economic development. Studies have shown that international trade and economic growth have a significant positive relationship, whereas sustained economic growth tends to amount to economic development (Were, 2015; Iyoha \& Okim, 2017). Thus, the assertion that international trade is a veritable instrument of economic development is not far from the fact. However, the poor economic positions of some countries that also engage in international trade arouses suspicion that merely engaging in international trade might not be sufficient to make a country better off economically. So, what shape must international trade assume in order for it to be able to nudge an economy on the path of prosperity?

Many trade theories made hypothetical assertions that countries are better off when they engage in international trade, but the supposed lofty gains were said to be attainable on certain terms subtly put forward by these theories. While many of the earliest international trade theories made effort to prove that the potential gain derivable from free trade outweigh those of mercantilism, they highlight various factors they believe prompt international trade without clearly stating if the suppose accrued benefits go both ways (Thirlwall, 2000). In another light, if a country, say country A is inclined to import some commodities from another country, say country B with comparative advantage over it in the production of the said commodities, is country B also expected to import those goods that it has lesser advantage in 
their production from country A? What if country A does not have comparative advantage in the production of the commodities in question over country B? What if country B has a trade pact with another country and does not feel obligated to import from country A, notwithstanding that country A imports some goods from country B and has comparative advantage in the production of some of the goods country B has lesser advantage in their production? International free trade does not seem to amount to economic development when it is seen as the unhindered random trade between countries as viewed by most developing countries. It tends to amount to economic development when it is rather seen as the trade amongst countries with a carefully thought-out pattern, forged through bilateral agreements and designed with the clear objective of engendering economic prosperity. This is not far from how the developed countries view international free trade.

The observation above explains why high income countries which are some of the major proponents of international free trade still have in place tariff and non-tariff barriers to international trade. Having access to the markets of the more advanced countries is a tricky issue for many developing countries; they tend to have a somewhat unhindered access when the export commodities are primary goods and/ or are not sufficiently produced locally. Aside the competitive disadvantage firms in developing countries experience due to the economies of scale huge rival firms in developed countries enjoy, some of the firms in the more advanced countries, especially those in the agricultural sector are also given subsidies. For some other goods, especially those that are produced locally, tariff and non-tariff barriers of trade are used to dissuade importation of these goods, giving advantages to local producers.

Many nations around the world, developing and developed alike put in place trade policies that brazenly and/ or tacitly discourage or impede importation of certain goods into their countries, by using quotas, tariffs, and tariff escalation among others. Anderson, Hoekman and Strutt (2001) estimate annual welfare losses of about $\$ 19.8$ billion for developing countries. This is said to be about three times the size of loss suffered by developing countries from Organization for Economic Cooperation and Development (OECD) import restrictions on textiles and clothing.

In many high income countries high tariffs are imposed on agricultural products, with the average tariff rate on agricultural products said to be almost the double of the tariff for manufactures. More specifically, more than one third of the European Union's agricultural tariff lines tend to carry duties above $15 \%$, with tariff peaks within the agricultural sector being common among processed products and temperate agricultural commodities. Strong tariff escalation is typically imposed on agricultural and food products by high income countries. This vehemently discourages the development of high value added exports, and hinders diversification in particular, as well as development in general.

Aside the two afore mentioned means through which barriers to trade are deliberately imposed by high income countries on imports from developing countries, complex tariff is also used. A complex tariff refers to the daunting challenges the means of accessing and processing information required to export goods to a country (in this case the industrialized countries) are fraught with. Non-tariff barriers to trade such as safety and standard regulations are often times used to reduce competition from other countries. Developing countries do not find it challenging to meet up with or comply to stipulated regulations or standards because they lack the capacities to do so, it is rather largely because these stipulations and standards are vague, and will always be said to be unattainable even when attained, since they are 
invisible walls used to ward off importation of certain goods in the most subtle manner. The fact that the said guidelines and standards are unilaterally imposed does not provide platform for commodities that fall within the category of those that fall short of requisite standards to be independently tested to ascertain the veracity of such claims.

Support to agricultural produces in high income countries is still huge; it is put at about five times the amount given out for international development assistance, which is about \$245 billion in 2000. The dumping of unwanted production surpluses onto the world market through subsidies tends to depress prices of a number of agricultural commodities in the international market. Within the same period, the total support to agriculture in the Organization for Economic Cooperation and Development (OECD) reached about $1.3 \%$ of the GDP of the member countries put together, put at about $\$ 327$ billion (Anderson, Hoekman \& Strutt, 2001).

Imposition of barriers to trade is also common in developing countries. Although the high dependence of these nations on imports from the industrialized nations, the high prevalence of corruption and poor implementation of policies tend to dampen the resolve of the progenitors of such policies and scuttle chances of achieving desired goals. Also, the governments of the developing nations are made to acquiesce to the pressure from the leaderships of the more advanced nations to rescind their resolves regarding imposed high tariffs or bans, using their influence in the Bretton wood institutions and international aids as leverages.

Import duty is a veritable source of revenue for developing countries, however, developing countries with expanding industrial sector and overzealous leaderships impose outright ban on certain goods that are locally produced, as they perceive the imported goods as threats to local industries. Outright ban has not proven to be an effective policy that spurs industrialization. This is because the absence of competition occasioned by the ban grants monopoly advantage to local producers and even erodes the economic gains that come with competition amongst the producers due to the scarcity that results from insufficient production. Hence, the local firms are not usually eager to fill the gap between quantity produced and quantity demanded, let alone producing at internationally competitive prices and qualities.

\section{International Monetary System and International Trade}

The international monetary system provides the means of payment acceptable to buyers and sellers of different nationalities, including deferred payments. Generally accepted means of payment between countries have taken different shapes and forms over several centuries; from the barter system to the use of precious metals, the use of coins made out of silver and gold to the use of fiat money, and the digital currencies in their various forms. Fiat money tends to be the most popular medium of exchange in recent times; even the variously adopted means of payments like checks, promissory notes, and credit transfers are mostly used in lieu of fiat money or have fiat money as the standard for measurement.

The exchange of goods for some other goods or for money is a venture that leaves the parties involved better off, else they would want to explore other options. Long before the industrial revolution period, trade was largely individualistic, that is, trade occurred mostly between individuals or groups of individuals. As at then, the aggregate trade between nations was given little or no consideration. This is not unrelated to the fact that the media of exchange were different from what obtains in the global economy presently. Media of exchange used for international transaction have origins that transcend one country, region or empire. Aside the barter system where goods were exchanged for other goods, some of the most popular 
means of exchange that held sway include silver, gold, gems and cowries among others. Even some of the first sets of bank notes offered in lieu of gold were issued by gold smiths with deposit of gold of the bearers of the bank notes. During this period, international trade thrived unabatedly as most of the rulers that reigned as it were benefited from these trades through tax remittances. However, the simple economics of buying and selling changed from simple to complex the moment most countries of the world introduced their various currencies.

The prevailing international monetary system in the world today is one that occasions most international transactions to be carried out in a basket of few currencies. Save for business transactions between neighbouring countries, most transactions between countries are carried out using currencies of some select countries as the media of exchange; and in that line, the currencies of the trading countries are first converted to one of the vehicle currencies before it is converted to the currency of the other trading country. These vehicle currencies include the United States Dollar, the European Union Euro, the British Pounds Sterling and the Chinese Yuan. Consequently, it behooves every country to not just engage in international trade but to also export goods and services in quantities and values that would afford it sufficient foreign exchange to facilitate importation seamlessly and to also ensure the stability of its currency. It is the demand and supply of a nation's currency that determines the exchange rate value of a nation's currency, while export of export goods brings about increase in the demand for a nation's domestic currency, import of import goods brings about increase in the demand for foreign exchange. Excessive demand for foreign exchange results in the devaluation of the local currency and increases the value of foreign currencies simultaneously, all things being equal (D'Arista, 2001).

When a country's import exceeds its export, it is said to have an unfavourable balance of trade, a disposition that will most likely lead to domestic currency devaluation if the negative gap continues to widen. A decrease in the exchange rate value of a country's currency, even though it makes a country's export more competitive in the international market, lowers standard of living through the reduction of the purchasing power of the domestic currency. Conversely, when export exceeds imports, it results in a favourable balance of trade which leads to the appreciation of the domestic currency. An increase in the exchange rate value of a domestic currency makes a country's export goods more expensive and less competitive in the international market. Save for commodities with low price and income elasticities, huge increases in appreciation of domestic currency could lead to decrease in export which could exert negative ripple effect on unemployment and personal income. However, appreciation of the domestic currency improves standard of living since imported goods become cheaper, leaving consumers with more money to carter for other needs (See table 2).

In situations where the major export goods are primary goods and are almost price and income inelastic, individual exporting countries are usually price takers and as such the quantities of export goods exported do not often change with changes in the exchange rate values. With the entrenchment of an international monetary system where most countries have their generally accepted unique means of exchange, which are mostly fiat money as obtainable in recent times, the gains accruable from international trade now transcends the immediate gains derivable from exporting or importing goods. The value of net export tends to affect the value of the currencies of nations, which invariably has implications on their economic development (Ball, 1982). Table 3 shows the balance of payments of select African countries and their average annual exchange rate. 


\section{Literature Review}

International trade theories could be broadly categorized into two: the traditional trade theories and the modern trade theories. The traditional trade theories which are also referred to as the classical trade theories are the postulations of Adam Smith and David Ricardo. Free trade as against the mercantilist policy of protectionism was championed by both Smith and Ricardo as a means to achieve production efficiency. The Adam Smith model describes trade taking place between countries as a result of the absolute advantage some countries have over others in the production of certain goods. Smith's international trade theory lays emphasis on minimization of aggregate real cost and efficient resource allocation without due consideration for comparative cost. The Ricardian theory of comparative advantage made effort to accommodate the perceived deficiencies in the Adam Smith absolute advantage theory. According to him, comparative advantage arises due to differences in technology or natural resources, albeit the theory fails to make a direct consideration of factor endowments. This loophole was filled by the Heckscher - Ohlin model which followed suit. It was developed by the duo Swedish Economists, Eli Heckscher and Bertil Ohlin who held the view that the pattern of trade is determined by differences in factor endowment.

The Stolper - Samuelson theorem is another fascinating trade theory that trailed the Heckscher - Ohlin theory. The theorem underscores the sequacious rise in income earned from resources that are not intensively used in its production that results from increase in the price of export commodities on one hand and also the attendant decrease in income earned from resources intensively used in its production that derives from fall in price of the export product. The Stolper - Samuelson theorem stipulates that an increase in the price of a good will cause an increase in the price of the factor used intensively in that industry and a decrease in the price of the other factor. The Leontief Paradox also generates interest; the empirical test of validity of the Heckscher - Ohlin theory by Wassily Leontief in 1953 led to the emergence of the Leontief's paradox. As a capital intensive country as it were, the United States in the study was expected to export capital intensive goods and import the labour intensive goods; the findings of the study reveals the opposite.

Modern international trade theories try to factor-in salient elements of trade that were not given due consideration by the traditional theories. The new trade theory by Paul Krugman considered factors like foreign direct investment of the large multinational corporations, monopolistic competition and increasing return to scale as tending to paint clearer picture of the nature and trend of international trade in the world today. Amongst the new theories is the New new trade theory as posited by Melitz in 2003. It stresses the advantage firms that engage in international transactions have over firms that produce only for the domestic market. Another interesting new trade theory is the Gravity trade model. The Gravity trade model is in consonance with the Newton law of gravity which is largely affected by physical size and distance. The gravity trade model suggests that the trend of international trade flows in the direction of countries of closer proximity and bigger economic size.

The economic model describing Dutch disease was developed by Max Corden and Peter Neary in 1982. The model explains the causal relationship between the increase in economic activity of a specific sector (usually the exploitation of natural resources), and the decline in economic activities in the other sectors (usually the manufacturing and agricultural sectors). They are of the position that this results from the revenue increases in the growing sector 
which leads to the appreciation of the domestic currency and makes export commodities from the other sectors to become more expensive and inadvertently less competitive.

The theory of "National Economics" is traceable to Friedrich List (1789 - 1846). He developed the 'National System' of political economy model wherein he advocated imposing of tariffs on imported goods, stating that the cost of a tariff should be seen as an investment in a nation's future productivity. List further argued that the inherent benefit of a universal free trade accruable to the global economy does disenfranchise the less industrialized countries. According to him, the accrual of the benefits of an unimpeded international free trade to all the nations of the world in a relatively even manner can only be realized if a large number of countries attain to as nearly the same degree as possible of industrialization and civilization, political cultivation and power as the most advanced countries. In his words "... a nation would act unwisely to endeavour to promote the welfare of the whole human race at the expense of its particular strength, welfare and independence. It is a dictate of the law of selfpreservation to make its particular advancement in power and strength the first principles of its policy" (Priestly, 2019).

There exist a number of empirical studies that relate to international trade and economic growth; albeit studies with emphasis on the role of international trade in improving economic development by increasing real income tend to be few. The empirical review is comprised of two categories; research works that lay emphasis on international trade and economic growth and development and those that made emphasis on Dutch disease respectively. Reviewing studies on Dutch disease has become imperative due to the scarce availability of studies that relate to international trade and economic development. A country with a depreciating currency and high inflation rate could also experience marginal increase in economic growth, and in that light the inimical economic effects that stem from unfavourable international trade outcomes are not easily noticeable. Also, Dutch disease gives a plausible explanation as to why and how international trade deleteriously affects economic development.

Taking cognizance of the findings of related studies wherein exports have been found to have positive effect on economic growth and also negative impact on economic growth obtainable in situations where primary goods comprise a large share of total exports, Kalaitzi and Chamberlain (2020) tried to investigate whether exports are the cause of the significant growth that has been experienced in the Gulf Cooperation Council (GCC) since the early 1970s. The findings of the study reveals that exports do not cause economic growth in Oman and United Arab Emirates, while the reverse is the case in Kuwait and Saudi Arabia.

Zahonogo (2016) investigated how trade openness affects economic growth in developing countries, with a focus on 42 sub-Saharan African countries covering the period 1980 to 2012 and using the pooled mean group estimation technique. The result of the study indicates that a trade threshold exists, below which greater trade openness has beneficial effects on economic growth and above which the trade effect on growth declines. His findings support the view that the relationship between trade openness and economic growth is not linear for subSaharan Africa.

Were (2015) empirically examined the differential effects of trade on economic growth and investment based on cross-country data. The results were found to be largely consistent with the positive impact of trade on economic growth as found in the literature. The results based on different categories of countries show that while trade has positively impacted on economic growth in developed and developing countries, its effects is insignificant for least 
developed countries (LDCs), which largely include African countries. Additional results nonetheless suggest that trade is a key determinant of foreign direct investment (FDI) across all country groups including LDCs.

In an attempt to underscore the impact of exchange rate on international trade, balance of payments and overall economic performance, Nacifa (2013) investigated the relevance of exchange rates in international trade by analyzing the impact that exchange rate volatility and misalignment have on international trade. The study made effort to explore whether exchange rate misalignments affect governments' decisions regarding trade policies using fixed effects models on a detailed panel data set comprising about 100 countries over a 10-year period (2000 - 2009). The finding of the study is generally in line with those of recent related studies supporting the importance of exchange rate misalignment, while disregarding that of exchange rate volatility.

Putting into consideration the antitrade sentiments that still persist, even with development concerns placed at the core of reform negotiations at the World Trade Organization, in which two thirds of the members are developing countries, Fabiosa (2008) considered the impact of agricultural trade liberalization and food consumption through changes in income and prices. He used quantified impacts of agricultural liberalization on economic growth and world commodity prices and traced their likely impacts on the food consumption of small and underrepresented stakeholders in developing countries. The results of his study show overriding evidence that poorer households in developing countries actually benefit more in terms of higher consumption as a result of agricultural trade liberalization.

Bearing in mind the potential inherent static and dynamic gains to be derived from trade between countries, and making emphasis on the fact that existing theories never suggested equitable distribution of these gains, Thirlwall (2000) used the main models of export-led growth to assess the veracity of the findings of recent studies that suggest that regional trade agreements reduce growth and investment while generalized trade liberalization in the form of unilateral tariff reductions improves growth performance. From his assessment, he concluded that most developing countries are constrained in their growth performance by a shortage of foreign exchange and could therefore grow faster with more export.

From the Dutch disease dimension, Oreiro and Silva (2019) attempted to use new developmentalist model of structural change to explain the income position of some middle income Latin American countries. They adopted a synthesis between ideas presented by the classical development theory and post Keynesian theory of demand led-growth to explain the Middle Income Trap (MIT) position of these countries, attributing it to the sudden appearance of the Dutch disease or seizure to neutralize it due to the discovery of natural resources and/ or the adoption of an external savings growth strategy.

With the assertion that resource poor nations outperform the resource rich nations, Muhammad (2018) tried to trace the history of the prevalence of the Dutch disease in Nigeria and how it affects manufacturing industry. His findings revealed that Dutch disease affects manufacturing and other performance indicators including capacity utilization, cost of production, and installed and actual efficiencies.

Abdlaziz, Naseem and Sleasman (2018) attempted to investigate the long-run relationship between oil price and value-added share of agriculture as a proportion of GDP in 25 oil exporting countries. They used the panel heterogeneous co-integration test and fully modified ordinary least squares (OLS), dynamic OLS and pooled mean group methods to examine the 
long-run effect of real oil price and real exchange rate on agriculture. The result of the study shows negative and significant effect of oil price and exchange rate on agriculture value added, indicating existence of Dutch disease and de-agriculturalization in oil exporting countries.

Andrade and Duarte (2017) investigated the impact of foreign aid on the economies of some central and eastern European countries through its effect on the real exchange rate, with the assumption that foreign aid has effects similar to a boom in natural resource. They used the General Method of Moments (GMM)-system estimator's model to establish the impact of capital flows on output growth via the determination of real exchange rate in a group of central and eastern European countries under scrutiny. They found the positive influence of external capital inflows, and in particular European structural funds in the determination of the real exchange rate for output growth rate in these economies.

Lopez (2017) made effort to analyze the phenomenon of premature deindustrialization for Columbia and seven other Latin American countries. He used a Koyek transformation model for the Columbian case, and panel data fixed effects model for the complete sample of eight Latin American countries. The study concludes that the fall in the average effective tariff in the region is the main economic explanation of the premature reduction in the manufacturing share. It also provides evidence that relates the negative performance of manufacturing to foreign investment flows and to Dutch Disease.

Nchor, Kolman, Strelec and Darkwah (2015) investigated the impact of the new oil sector on the economic performance of major traditional sectors of the Ghanian economy. They used Autoregressive Distributed Lag (ARDL) Model to evaluate the impact of oil resource on traditional sectors of the Ghanaian economy via effective exchange rate. The results from the study show that there is no clear case of declining performance of the sectors in terms of output, growth and export earnings as a result of the recent oil production. The study could also not establish a sustained appreciation in the real effective exchange rate since commercial oil production commenced, which does not indicate the presence of Dutch disease.

In his attempt to answer the question posed by Easterly (2003) "Can foreign aid spur growth?" Kallon (2014) investigated the long-run relationship between foreign aid, real exchange rate, trade balance and economic growth in Sierra Leone using the VAR model. His findings reveal that Dutch Disease hypothesis does not hold for Sierra Leone. Accordingly, even though foreign aid is associated with long-run economic growth, its negative impact on the real exchange rate lowers the real income of cash crop farmers, which raises the level of poverty and income inequality in the country.

Hodge (2012) made effort to ascertain the nature of the relationship between real exchange rate and manufacturing in South Africa using Johansen VAR/ VEC co-integration approach. He found that world growth is the single most important determinant of domestic manufacturing, while the real exchange rate has the predicted negative relationship, showing no evidence of Dutch disease specific effect on manufacturing.

Martins (2011) investigated whether large inflows of foreign aid and remittances have had damaging impact on the Ethiopian real exchange rate using a structural time series model. His results suggest that there are two main long-run determinants of real exchange rate in Ethiopia: while trade openness is found to be correlated with real exchange rate depreciations, a positive shock due to the terms of trade tends to appreciate the real exchange rate. 
In an attempt to shed light on the blurry relationship between the economy of Botswana and the Dutch disease, Makochekanwa (2009) embarked on a study in an attempt to ascertain why Botswana's economy defies the predicted resource curse. He employed the gravity trade model to test the Dutch disease hypothesis on the country's main export product from the manufacturing, mining and agriculture sectors. The result of the study indicated that diamond exports boosted exports from manufacturing, mining and agricultural sectors instead of hurting the country's exports.

Rajan and Subramanian (2009) examined the effects of aid on the growth of manufacturing in 47 significant aid receiving low income countries, using a methodology that exploits the variation within countries across their manufacturing sectors and corrects for possible reverse causality. They found that aid inflows have systematic adverse effects on a country's competitiveness, as reflected in the lower relative growth rate of exportable industries.

Budina, Pang and Wijnbergen (2007) investigated the possibility of Nigeria's government expenditure extreme volatility through debt-funding as being behind the country's disappointing non-oil growth record since the 1970s instead of the Dutch disease. The study found out that although Nigeria experienced an oil boom in the past, the oil boom failed to halt the country's continued stagnation in the non-oil economy of the country. After a careful examination of the macroeconomic policies over the years and government's management of the wind fall oil revenues, the study concluded that extreme volatility of government's expenditure is the main cause of the disappointing non-oil growth record and not the Dutch disease. The study attributed the country's unfavourable fiscal position to inefficient policies and even worse, government's expenditure which is even more volatile than income.

Levy (2006) embarked on the study of the relevance of agricultural policies in putting Dutch disease at bay in Chad. She used a computable general equilibrium model calibrated for Chad to evaluate the impact of using the country's annual oil revenue for public investment, particularly in the development of road and irrigation infrastructures. She found that improving water access would improve Chad's dependence on food aid and entail a substantial improvement in rural household welfare.

Algieri (2004) took steps in his work to show how Dutch disease has affected the Russian economy since the start of the transition in the early 1990s. He used an extended version of the Balassa - Samuelson model to test one out of four detected symptoms of Dutch disease: (i) real exchange rate appreciation (ii) a temporary improvement in economic situation (iii) decline in the non-booming sector, and (iv) export reduction in the non-booming sector. From his findings it could be deduced that the Russian economy exhibits all the symptoms and is thus infected by the Dutch disease and largely vulnerable to exogenous shocks.

Fielding and Gibson (2011) examined aid inflows in 26 sub-Saharan African countries using a simple time-series model in which the effect of aid on relative prices and output is estimated in reduced form to estimate the impact of aid inflows on the real exchange rate and output. The findings reveal that aid inflows cause a real exchange rate appreciation in most of the countries. 


\section{Research Method}

\subsection{Theoretical Framework}

The study is anchored on List's "National Economics" model. Friedrich List (1789 - 1846) developed the National Economic model as written in his most famous work, National System of Political Economy (1841). As stated in his book, List expressed his conditional support for free trade despite his opposition to unbridled free trade as advocated by the laissez-faire proponents. According to him, nations pass through four stages in their economic development process and that a nation's trade policies should correspond to its current stage of development. Consequently, List advocates that countries should engage in free trade only in the first and last stages of development, as doing so in the intermediate (second and third) stages of development could hamper a nation's progress as it seeks to move through the stages (Priestly, 2019).

List viewed the economies of individual countries and the economy of the entire world as two extremes and holds that countries' economies, especially during their intermediate stages of development are better considered when viewed from an individual nation point of view, which is what he termed 'national economics.' List started out as an opponent of the practice of free trade on the basis that underdeveloped nations are not yet ready for foreign competition. To some point, List does agree with Smith that free trade is ideal, but holds that if it were implemented before a nation' manufacturing sector were mature, then free trade would result in a country's market being dominated by stronger countries with more mature manufacturers, and thus, their national interests would be undermined. In that line of thought, List supported free trade within a country, but recommends the use of tariffs during trades between countries to protect infant industries.

List's fundamental doctrine was that a nation's true wealth is the full and many sided development of its productive power rather than its current exchange values. He also opined that an economically mature nation is a nation with a developed agriculture, manufacturing and commercial sectors. However, the last two sectors are more important, since they better influence the nation's culture and independence and are especially connected to navigation, railways and high technology. Friedrich List's theory does not argue against free trade, he rather argues against unconditional removal of the various import restrictions whose unavailability would not only scuttle the revenues accruable to the government in the form of import duties and tax receipts but could also put a nation's productive capacity in near peril, especially when done at economically unhealthy stages of development of the country. This is informed by the believe that the ultimate benefit derivable from engaging in international trade is improvement of the average welfare of the citizenry of the participating countries.

\subsection{Model Specification}

Taking a cue from Iyoha and Okim (2017) who specified economic growth as a direct function of export proceeds and other economic occurrences affected directly or indirectly by international trade, and giving it a tilt to accommodate arguments made in the work, the study thereby expresses economic development as a function of balance of payments which is largely determined by net export of goods and services, the countries' states of economic development and other relevant economic factors.

The functional relationship is therefore specified as follows: 


$$
\mathrm{ECM}=\mathrm{f}(\mathrm{GPC}, \mathrm{BOP}, \mathrm{TEX}, \mathrm{MEX}, \mathrm{EXC})
$$

We take the first-lag of the dependent variable and re-specify equation (1) in dynamic panel econometric model as:

$$
\mathrm{ECM}=a_{0}+a_{1} \mathrm{ECM}_{t-1 i t}+a_{2} G P C_{i t}+a_{3} B O P_{i t}+a_{4} T E X_{i t}+a_{5} M E X_{i t}+a_{6} E X C_{i t}+\gamma_{i t}+
$$

Where:

$\mathrm{ECM}=$ Economic misery

$\mathrm{ECM}_{t-1}=$ First-lag of economic misery, the dynamic variable

$\mathrm{GPC}=$ Annual GDP per capita growth rate

$\mathrm{BOP}=$ Balance of payment

TEX $=$ Total export as percentage of GDP

MEX $=$ Manufacture export as percentage of merchandise trade

$\mathrm{EXC}=$ Average annual exchange rate per US dollar

$\gamma_{i t}=$ a between-country error term

$\varepsilon_{i t}=$ a within-country error term

$\mathrm{i}=$ observational units

$\mathrm{t}=$ time

\subsection{Method of Estimation}

The Arellano-Bover/ Blundell-Bond System Generalized Method of Moments (SystemGMM) estimation technique is employed in estimating equation (2). This technique is more appropriate and hence adopted, given the fact that the presence of $\mathrm{ECD}_{t-1}$ in equation (2) could lead to autocorrelation. Also, GPC and TEX are likely to be endogenous, in addition to the time-invariant country-specific characteristics (the country-fixed-effects) such as geography and demography that could correlate with the explanatory variables. The countryfixed-effects are captured in the error term which is comprised of both the unobserved country-specific effects $\left(\gamma_{i t}\right)$ and the observed specific errors $\left(\varepsilon_{i t}\right)$ as specified in equation (2). Acemoglu, Johnson, Robinson and Yared (2009) are of the position that endogeneity and other econometric problems inherent in the dependent and independent variables' dynamics can be solved using GMM. Also, GMM will still produce robust estimates even if the models were to be heteroscedastic or have correlation errors (Nawaz, Iqbal \& Khan, 2014).

The instruments could be weak at the first-stage of the two-staged least square (2SLS) regressions if the fixed-effects instrumental variables estimation (two-staged least squares or 2SLS) technique is employed. In that light, the technique will result to bias and inconsistent estimates that suggest $\varepsilon_{i t}$ is independently and identically distributed (i.i.d). The presence of, say $\gamma_{i t}$ in the equation for estimation makes both the standard fixed effect and random effect estimators to be inconsistent. Again, the system GMM estimator is about the most appropriate estimator in this circumstance since it makes use of variables in their level form with lagged differences as instruments. The GMM estimator which combines the moments conditions of the model in first differences and those of the model in levels (differences are used as instruments for the level equations) is known as system-GMM. This allows for estimation 
with lower bias and higher accuracy (Bond, 2002; Arellano \& Bover, 1995; Blundell \& Bond, 1998).

Also, it is appropriate to begin the estimation with the test of stationarity of the variables. Consequently, the stationarity of the variables will be tested using the Im, Persaran and Shin IPS (2003) test and Breitung and Das (2008) test. The IPS test is a t-bar statistic dependent on the augmented Dickey-Fuller Statistics (Dickey \& Fuller, 1979). The Kao test is employed to test for the cointegration of the variables. On the other hand, the post estimation tests to be conducted include: the Wald chi2 (11) test, Arellano-Bond test for zero autocorrelation and the Sargan test of over identifying restrictions.

\subsection{Data and Data Sources}

The data for the study are sourced from the World Development Indicators (World Bank, 2019); the study is comprised of 17 African countries and cover the period 1995 to 2018. The dependent variable is economic misery and is measured by the Arthur Okun's misery index. Dudley Seers (1969) is of the position that economic development is largely about what happens to income, unemployment, unemployment and inequality. In that light, the Okun's misery index factors-in the impact of unemployment and rate of inflation in its measure of the lack of economic development, making it an appreciably good measure considering the complexity of the concept and the traits it exudes. The lagged form of economic misery is one of the independent variables used in the study. This depicts List's argument that a country's stage of development should determine its trade policy, which invariably determines the impact of international trade on a country's economic development.

Other independent variables used in the study include economic growth, net export, total export, manufacture export and exchange rate. As a core determinant of economic development, economic growth was introduced into the model as a control variable; the annual GDP per capita growth rate is used to measure economic growth. Balance of payments was used in lieu of net export, since net export makes huge contribution towards its outcome and captures more effectively the impact of the external sector on exchange rate and economic development in general. Total export is measured by total export as percentage of GDP; the total value of export commodities as a proportion of total economic activities of the individual countries is captured here. It has been argued that the composition of the basket of export goods of a country determines the nature of the impact of its trade with other countries on its economy, especially manufactures as against primary commodities. Manufacture export is measured by manufacture export as percentage of merchandise trade. Exchange rate is measured by the average annual exchange rate per US dollar.

\section{Finding and Discussion}

Estimation of the regression equation was preceded by an examination of the descriptive statistics of the variables in the model. This is to have a glimpse of the time-series behaviour of the pooled panel data set for the study. The result is presented in Table 4 below.

From Table 4, BOP, TEX, MEX, GPC and EXC have standard deviation values that are close to their respective mean values. That is, the values of balance of payment, total exports, manufacturing exports, GDP per capita growth rate and exchange rate hover around their respective mean values. The value of economic misery on the other hand, has high standard deviation value, which is far greater than its mean value. This means that the variable is farther away from its mean value. The minimum values of all the variables are less than their 
respective mean values, while the maximum values of the variables are greater than their mean values respectively. The skewness test shows significant $p$-values for all the variables at the 5 per cent level except for GDP per capita growth rate. Therefore, the null hypothesis of the normal distribution of the variables is rejected except for GDP per capita that is accepted at the 5 per cent level. Similarly, for the Kurtosis test, the significant p-values indicate that the variables are significantly different from the kurtosis of normal distribution at the 5 per cent level

Table 4. Mean, standard deviation, maximum values, minimum values, skewness and kurtosis of the variables

\begin{tabular}{|lllllll|}
\hline Variables & ECM & BOP & TEX & MEX & GPC & EXC \\
\hline Mean & 142.682 & -1.1600 & 27.9804 & 20.9075 & 2.4192 & 2.3800 \\
\hline Standard Deviation & 1710.872 & 4.7500 & 15.8265 & 17.0996 & 4.8287 & 4.8100 \\
\hline Minimum value & -3.1402 & -2.3600 & 5.1508 & 0.2069 & -36.8299 & 0.0087 \\
\hline Maximum value & 24529.63 & 2.4400 & 87.2831 & 76.1356 & 36.9809 & 9.7200 \\
\hline Pr(Skewness) & 0.0000 & 0.0000 & 0.0000 & 0.0000 & 0.1065 & 0.0000 \\
\hline Pr(Kurtosis) & 0.0000 & 0.0000 & 0.0000 & 0.0012 & 0.0000 & 0.0000 \\
\hline Obs. & $\mathrm{N}=408$ & $\mathrm{~N}=408$ & $\mathrm{~N}=408$ & $\mathrm{~N}=408$ & $\mathrm{~N}=408$ & $\mathrm{~N}=408$ \\
& $\mathrm{n}=17$ & $\mathrm{n}=17$ & $\mathrm{n}=17$ & $\mathrm{n}=17$ & $\mathrm{n}=17$ & $\mathrm{n}=17$ \\
& $\mathrm{~T}=24$ & $\mathrm{~T}=24$ & $\mathrm{~T}=24$ & $\mathrm{~T}=24$ & $\mathrm{~T}=24$ & $\mathrm{~T}=24$ \\
\hline
\end{tabular}

Source: Author's Computation

From Table 5, none of the p-values of the variables, according to the Breitung test is significant at levels. Therefore, the variables were differenced once and the test was conducted again. At their first difference, all the variables became significant at the 5 per cent level. For this reason, the null hypothesis that all panels contain unit roots is rejected, implying that the variables are integrated of order one, I(1). The Im, Pesaran and Shin (IPS) test also show a similar result. At level, none of the test statistics was significant. However, at their first difference, the test statistics of the variables were significant, hence, supports the rejection of the null hypothesis at the 5 per cent level. In essence, the test results from both tests show that the variables are integrated of order one, I(1).

The variables were also tested for unit root using the Breitung and the Im, Pesaran and Shin (IPS) unit root tests and the results are presented in Table 5 below

Table 5: Breitung and Im, Pesaran and Shin (IPS) unit root test results

\begin{tabular}{|c|c|c|c|c|c|}
\hline \multirow[t]{2}{*}{ Variable } & \multicolumn{2}{|c|}{$\begin{array}{l}\text { Breitung unit-root } \\
\text { Test Result }\end{array}$} & \multicolumn{2}{|c|}{$\begin{array}{l}\text { Im, Pesaran and Shin (IPS) } \\
\text { Test Result }\end{array}$} & \multirow[t]{2}{*}{$\sim \mathrm{I}(\mathbf{d}$} \\
\hline & Level & $\underline{1}^{\text {st }}$ Difference & Level & $\underline{1}^{\text {st }}$ Difference & \\
\hline ECD & $\begin{array}{l}-1.9745 \\
(0.1577)\end{array}$ & $\begin{array}{l}-9.4419 * \\
(0.0000)\end{array}$ & $\begin{array}{l}-1.2110 \\
(0.1622)\end{array}$ & $\begin{array}{l}-5.2654 * \\
(0.0000)\end{array}$ & $\mathrm{I}(1)$ \\
\hline BOP & $\begin{array}{l}-1.4362 \\
(0.0755)\end{array}$ & $\begin{array}{l}-11.5396^{*} \\
(0.0000)\end{array}$ & $\begin{array}{l}1.8763 \\
(0.9697)\end{array}$ & $\begin{array}{l}-10.1945^{*} \\
(0.0000)\end{array}$ & $\mathrm{I}(1)$ \\
\hline
\end{tabular}


Vol 2 No. 4, December 2021

\begin{tabular}{|c|c|c|c|c|c|}
\hline \multicolumn{6}{|c|}{ Table 5. Continued } \\
\hline Variable & \multicolumn{2}{|c|}{$\begin{array}{l}\text { Breitung unit-root } \\
\text { Test Result }\end{array}$} & \multicolumn{2}{|c|}{$\begin{array}{l}\text { Im, Pesaran and Shin (IPS) } \\
\text { Test Result }\end{array}$} & \multirow{2}{*}{$\begin{array}{l}\sim \mathrm{I}(\mathrm{d}) \\
\mathrm{I}(1)\end{array}$} \\
\hline TEX & $\begin{array}{l}-0.0010 \\
(0.4996)\end{array}$ & $\begin{array}{l}-8.3740^{*} \\
(0.0000)\end{array}$ & $\begin{array}{l}-0.7902 \\
(0.2147)\end{array}$ & $\begin{array}{l}-10.9204 * \\
(0.0000)\end{array}$ & \\
\hline MEX & $\begin{array}{l}-1.8710 \\
(0.1621)\end{array}$ & $\begin{array}{l}-4.7394 * \\
(0.0000)\end{array}$ & $\begin{array}{l}-0.3619 \\
(0.6115)\end{array}$ & $\begin{array}{l}-5.0870 * \\
(0.0000)\end{array}$ & $\mathrm{I}(1)$ \\
\hline GPC & $\begin{array}{l}-0.0381 \\
(0.2311)\end{array}$ & $\begin{array}{l}-4.5191 * \\
(0.0000)\end{array}$ & $\begin{array}{l}-0.1641 \\
(0.3217)\end{array}$ & $\begin{array}{l}-9.0174 * \\
(0.0000)\end{array}$ & $\mathrm{I}(1)$ \\
\hline EXC & $\begin{array}{l}-1.9367 \\
(0.7061)\end{array}$ & $\begin{array}{l}-13.6748^{*} \\
(0.0000)\end{array}$ & $\begin{array}{l}-0.6929 \\
(1.0000)\end{array}$ & $\begin{array}{l}-10.4575^{*} \\
(0.0000)\end{array}$ & $\mathrm{I}(1)$ \\
\hline \multicolumn{6}{|c|}{$\begin{array}{l}\text { (1) The Breitung and the IPS p-values are presented in parenthesis. } \\
\text { (2) * denotes significant at } 5 \% \text { and the rejection of the null hypothesis of the } \\
\text { panels containing unit-roots. }\end{array}$} \\
\hline
\end{tabular}

Source: Author's Computation

Since the variables are integrated of the same order, the cointegration of the variables was examined using the Kao panel cointegration test and the result is presented in Table 6 below.

Table 6. Result of Kao test for cointegration

\begin{tabular}{|lll|}
\hline Test Statistics & \multicolumn{1}{l}{ Statistic } & p-value \\
\hline Modified Dickey-Fuller t & -21.9151 & 0.0000 \\
\hline Dickey-Fuller t & -14.9659 & 0.0000 \\
\hline Augmented Dickey-Fuller t & -7.8063 & 0.0000 \\
\hline Unadjusted modified Dickey-Fuller t & -23.2544 & 0.0000 \\
\hline Unadjusted Dickey-Fuller t & -15.0484 & 0.0000 \\
\hline $\begin{array}{l}\text { The model underlying the reported statistics includes panel-specific means and } \\
\text { panel-specific AR parameters and does not include a time trend. Bartlett kernel } \\
\text { with } 2 \text { lags was used, as selected by the Newey-West methods, to adjust for serial } \\
\text { correlation. }\end{array}$ \\
\hline
\end{tabular}

\section{Source: Author's Computation}

The reported statistics of the Kao test are all significant. For this reason, the null hypothesis of no cointegration is rejected at the 5 per cent level. This means that there is cointegration among the variables in the regression model. The model specified for the objectives was estimated using the system GMM estimator. The result is presented in Table 7 below. 
Vol 2 No. 4, December 2021

Table 7: System GMM regression result

\begin{tabular}{|c|c|c|c|c|}
\hline RGDP & Coefficients & Standard Errors & t-stat & P-value \\
\hline BOP & 1.6500 & 1.2600 & 0.01 & 0.990 \\
\hline TEX & 17.1373 & 6.3211 & 2.71 & 0.007 \\
\hline MEX & 30.7633 & 8.5333 & 3.61 & 0.000 \\
\hline GPC & 26.8169 & 8.3272 & 3.22 & 0.001 \\
\hline EXC & 2.1800 & 9.2500 & 23.59 & 0.000 \\
\hline $\mathbf{E C M}_{\mathrm{L}-1}$ & 0.0060 & 0.0038 & 1.58 & 0.114 \\
\hline Constant & -741.8087 & 368.9474 & -2.01 & 0.044 \\
\hline $\begin{array}{l}\text { Wald chi2(8) } \\
\text { Arellano-Bond Test: } \\
\text { AR (1) } \\
\text { AR (2) } \\
\text { Hansen Test }\end{array}$ & & $\begin{array}{r}-0.96151(p=0.3363) \\
-1.186(p=0.2 \\
6.6696(p=1.000\end{array}$ & & \\
\hline
\end{tabular}

\section{Source: Author's Computation}

From Table 7, balance of payments has a positive coefficient of 1.6500 with a t-value of 0.01 . The insignificant $t$-value of 0.01 indicates the acceptance of the null hypothesis and suggests that balance of payments has no statistically significant effect on economic misery. The insignificant $\mathrm{p}$-value means that there is a significant error in rejecting the null hypothesis. The coefficient for total export is 17.1373 with a t-value of 2.71. Since the t-value of 2.71 is significant, the null hypothesis of total export having no statistically significant effect on economic misery is rejected at 5 per cent level of significance. The significant p-value indicates that there is an insignificant error in rejecting the null hypothesis.

Similarly, manufacture export has a positive and statistically significant effect on economic misery while GDP per capita growth rate has a coefficient of 26.8169 , with a t-value of 3.22. Exchange rate has a positive coefficient of 2.4600 with a significant t-value of 23.59. The positive coefficient of the lag of economic misery $\left(\mathrm{ECD}_{\mathrm{L}-1}\right)$ implies that the current level of misery is also determined by the initial level of misery.

The significant Wald chi2(9) p-value indicates that the explanatory variables have a joint significant impact on the dependent variable. The p-values of the Arellano-Bond test for the first and second-order autocorrelation are statistically insignificant at the 5 per cent level. Therefore, the null hypothesis of no first and second-order autocorrelation in the disturbance term cannot be rejected. The Hansen test confirms the validity (homogeneity) of the set of instruments. The null of the validity of the instruments is accepted, given the insignificant Hansen p-value.

\section{Conclusion}

The study examined the effect of international trade on economic misery in select African countries, in an effort to determine the impairments that tend to impede African countries from optimally reaping the developmental gains inherent in partaking in international trade which seems to also worsen the economic misery the populations endlessly contend with. The findings of the study reveal that balance of payments, total export, manufacture export, per capita GDP growth rate, exchange rate and lagged form of economic misery all have positive effect on economic misery. While the effects of total export, manufacture export, per capita 
GDP growth rate, and exchange rate on economic misery are significant, those of balance of payments and lagged form of economic misery are insignificant. From the results of the analyses it could be deduced that many African countries have external sectors that are not structured in ways that engender economic development, even when they experience marginal increases in exports. Put differently, the engagement of Africa in international trade as it were stands to exacerbate economic misery of the continent instead of prompting improved economic wellbeing.

From the results of the analyses above, the study is of the position that total export, manufacture export, per capita GDP growth rate and exchange rate are more inclined to worsen economic misery than improve economic development in Africa, given the prevailing modus of their engaging in international trade. There are a number of reasons as to why the relationships between these variables have assumed unusual dimensions. That increase in total export stands to bring about increase in economic misery should conventionally suggest the existence of Dutch disease, notwithstanding the glaring records of steady depreciation of the exchange value of the countries in question. However, that increase in manufacture export would amount to increase in economic misery makes the two scenarios inextricably complicated. Increase in manufacture export should imply that new industries will be built and while the older ones get refurbished, and all things being equal, more persons get employed while economic misery wanes down.

An opposite of the scenario painted above, wherein increase in manufacture export spurs increase in economic misery as could be deduced from the result of the analyses suggests two possible scenarios. Firstly, that most of the newly established industries that occasion increase in manufacture export and total export generally, are either infant small scale industries trying to get on their feet or are struggling existing industries attempting to compete with the huge multinational corporations by spreading their tentacles beyond the border. In both cases they eventually go moribund, since the state of economic misery of the inhabitants of these countries becomes worse off; an anathema that can hardly be the case if more persons get permanently employed. Secondly, that the standard of living of the newly employed workers as a result of the recent increase in total export and that of all workers in general become worse off due to the continuous fall in the exchange rate value of the domestic currencies of the countries in question. Currency depreciation results from unfavourable balances of trade and the attendant foreign exchange scarcity that characterize it. The inability of increase in total export to offset negative trade balances is another reason why increase in manufacture export and total export would not improve economic welfare.

In the light of the above, policy makers, governments of African countries and indeed those of other developing countries should first and foremost among other things ensure that trade with the rest of the world results in favourable balance of trade and positive balance of payments, and whenever there is a contrary trade outcome it should not be sufficient to negatively affect exchange rate. Other efforts should include encouraging the production of commodities of the manufacturing sector extraction. They could achieve this by channeling concerted effort towards improving the production capacities of existing domestic industries and building new industries, ether by creating investment companies or by providing adequate support to entrepreneurs. Initiating financial policies that stipulate apportioning a sizeable proportion of loanable funds to the industrial sector at lower interest rates and the establishment of industrial estates equipped with adequate infrastructures that will facilitate seamless industrial production are some of the ways to grow industrial capacities. 
Also, obsolete trade policies such as outright ban on importation of certain commodities should be jettisoned. Trade policies should be formed from an informed position after due consideration of the stages of development of the countries in question and their core development objectives. Import tariffs should be effectively adjusted such that it improves competitive advantage of the local producers and at the same time spurs improvement in quality and quantity of goods and services produced. Import duties provide a semblance of a fair pedestal for local firms to compete with foreign firms which are usually large multinational corporations who enjoy the benefits of economies of scale. However, when the tariff is too high, just like in cases of outright ban, local firms become reluctant to improve quality and quantity of goods produced and services rendered, since they would already be making mind boggling profits. Generally, international trade on goods and services and other formal and informal international transactions should be largely controlled such that they nudge these economies along the path of improved economic development.

Bilateral trade agreements should also be forged by policy makers since they stand to provide the spring board for local manufacturers to soar higher in the international market and better the chances of recording favourable balance of payments. Multilateral trade agreements have not convincingly proven to have positioned developing countries to reap the potential gains accruable from international trade, this is likely so because some of the signatory countries could be at different development stages as posited by Friedrich List, and in that regard, what works for country A may not work for country B.

\section{References}

Abdlaziz, R. A., Naseem, N. A., \& Slesman, L. (2018). Dutch disease effect of oil price on agriculture sector: Evidence from Panel Co-integration of Oil Exporting Countries. International Journal of Energy Economics and Policy, 8(5), 241 - 250.

Acemoglu, D., Johnson, S.,Robinson, A., \& Yared, P. (2009). Revaluating the modernization hypothesis. Journal of Monetary Economics, 56(8), 1043 - 1058.

Acosta, P. A., Lartey, E. K. K., \& Mandelman, F. S. (2009). Remittances and the Dutch disease. Working Paper No. 2007-8a, Federal Reserve Bank of Atlanta, Atlanta, GA.

Algeri, B. (2004). The effects of the Dutch Disease in Russia, ZEF Discussion Papers on Development Policy, 83, University of bonn, Centre for Development Research (ZEF), Bonn.

Anderson, K., Hoekman, B. \& Strutt, A. (2001). Agriculture and the WTO: Next Steps. Review of International Economics 9(2), 192 - 214.

Andrade, J. S. \& Duarte, A. P. (2017). Dutch disease in central and eastern European countries. Centre for Business and Economics Research Working Papers, No. 3, University of Coimbra.

Arellano, M. \& Bover, O. (1995). Another look at instrument variable estimation error component models. Journal of Econometrics 87(1), 115 - 143. 
Ball, R. J. (1982). The international trade and monetary system. In: Money and Employment. Palgrave MacMillan, London. Retrieved from https://doi.org/10.1007/978-349-166954-6.

Blundell, R. \& Bond, S. R. (1998). Initial conditions and moments conditions in dynamic panel data model. Journal of Econometrics, 87(1), 115 - 143.

Bond, S. R. (2002). Dynamic panel data models: A Duide to Micro Data Method and Practice. Portuguese Economic Journal, 1, 141 - 162.

Botta, A., Godin, A. \& Missaglia, M. (2015). Finance, foreign (direct) investment and Dutch disease: The Case of Columbia. Greenwich Political Economy Research Centre, GPERC15

Breitung, J. \& Das, S. (2003). Testing for unit roots in panel with a factor structure. Econometric Theory, 24(1), $88-105$.

Budina, N., Pang, G. \& Wijnbergen, S. S. (2007). Nigeria's growth record: Dutch Disease or Debt Overhang? World Bank Policy Research Working Paper, WPS 4256, Washington D.C, USA.

Central Intelligence Agency (2019). "The world factbook." Retrieved from https://www.CIA.gov/the-world-factbook/countries.

Coleman, C. (2020). The future of the African economy. Retrieved from https://www.weforum.org/agenda/2020/02/africa-global-growth-economicsworldwide-gdp/.

Corden, W. M. (1984). Booming sector and Dutch disease economics: Survey and consolidation. Oxford Economic Papers, 36, 359 - 380.

Corden, W. M. \& Neary, J. P. (1982). Booming sector and de-industrialization in a small open economy. The Economic Journal, 92, 825848.

D'Arista, J. (2009). The role of the international monetary system in Financial I action. Political Economy Research Institute (PERI) Conference on Financial I action of the Global Economy, University of Massachusetts, Amherst.

Dickey, A. A \& Fuller, W. A. (1979). Distribution of the estimators for autoregressive time series with a unit root. Journal of the American Statistical Association, 74(366), 427 431.

Eromenko, I. (2016). "Do remittances cause Dutch disease in resource poor countries of Central Asia?" MPRA Paper 74965, University Library of Munich, Germany.

Easterly, W. (2003). Can foreign aid buy growth? Journal of Economic Perspectives, 17(3), $23-48$.

European Union (2019). The Africa-EU partnership. Retrieved from www.ica-eupartnership.org/en/afcfta. 
Ezenekwe, U. R., Umeghalu, C. C. \& Uzodigwe, A. A. (2018). Oil export earnings instability and standard of living nexus in Nigeria. International Journal Of Economics, Commerce and Management, 6(6), 176 - 198.

Fabiosa, J. F. (2008). What effect does free trade in agriculture have on developing country populations around the world? CARD Working Paper, 486, 1 - 18.

Fielding, D. \& Gibson, F. (2011). Aid and Dutch Disease in sub-Saharan Africa. University of Otago Economic Discussion Papers 1108.

Gylfaso, T. (2014). Natural resources and economic growth: What is the Connection? CES info Working Paper, 530, Centre for Economic Studies and ifo institute (CESifo), Munich.

Iyoha, M. \& Okim, A. (2017). The impact of trade on economic growth in ECOWAS countries: Evidence from Panel Data. CBN Journal of Applied Statistics 8(1), 23 - 49.

Hodge, D. (2012). The exchange rate, Dutch disease and manufacturing in South Africa: What do the Data Say? Economic Research Southern Africa (ERSA) Working Paper 281.

Im, K. S., Pesaran, M. \& Shin, Y. (2003). Testing for unit roots in heterogeneous panels. Journal of Econometrics, 115(1), $53-74$.

Kalaitzi, A. S. \& Chamberlain, T. W. (2020). Exports and economic growth : Some Evidence from the GCC. International Advances in Economic Research, retrieved from https://doi.org/10.1007/s11294-020-09786-0, June, 2020.

Kallon, K. M. (2014). Foreign aid and the Dutch Disease: Evidence from SierraLeone. Centre for the study of African Economies Conference, 2014, University of Oxford, Oxford, UK.

Khiyari, P. K., Moghaddasi, R. \& Yazdani, S. (2013). Investigating factors affecting the international trade of agricultural products in developing countries. Life Science Journal, 10(3), $409-414$.

Lartey, E. K. K. (2007). Capital flows and the real exchange rate: An empirical study of subSaharan Africa. The journal of International Trade and Eonomic Development, Taylor \& Francis Journals, 16(3), 337 - 357.

Levy, S. (2006). Public investment to reverse Dutch disease: The Case of Chad. International Food Policy Research Institute, Development Strategy and Governance Division Discussion Paper 35, Washington D.C.

Lopez, M. H. (2017). Trade liberalization and premature deindustrialization in Columbia. Journal of Economic Structures, 6(30), 1- 30.

Makochekanwa, A. (2009). An empirical test of the Dutch disease hypothesis on Botswana's main exports. Retrieved from www.gtap.agecon.purdue.edu/...

Martins, P. (2011). Do large inflows hinder competitiveness? The Dutch Disease in Ethiopia. Applies Economics, 45(08), 1075 - 1088. 
Muhammad, M. (2018). Resource curse and the manufacturing industry in the twenty first century Nigeria. Techno Science African Journal, 15(2), 93 - 108.

Nacifa, A. (2013). Exchange rate, international trade, and trade policies. Policy issues in international trade and commodities study series 56, 1 - 22.

Nawaz, S., Iqbal, N., \& Khan, M. A (2014). The impact of institutional quality on economic growth: Panel Evidence. The Pakistan Development Review, 53(1), 15 - 31.

Nchor, D., Kolman, P., Strelec, L. \& Darkwah, S. A. (2015). The new oil sector and the Dutch disease: The Case of Ghana. Acta Universitatis Agriculturae et Silviculture Mendelianae Brunensis, 63(6), 2035 - 2041.

Oreiro, J. L. \& Silva, K. M. (2019). A new development model of structural change, economic growth and middle-income trap. Retrieved from https://www.researchgate.net/publication 336146756, June,2020.

Priestly, M. (2019). Friedrich List and national development, working paper no. 13. Portland State University Economics Working Papers, 13.

Rajan, R. G. \& Subramanian, A. (2009). Aid, Dutch Disease, and manufacturing growth. Centre for Global Development Working Paper 196.

Seers, D. (1969) The Meaning of development. Peason Education Limited, 11, 14 - 19.

Thirlwall, A. P. (200). Trade, trsde liberalization and economic growth: Theory and Evidence. African Development Bank Economic Research Papers, 63, 1 - 28.

Verter, N. (2017). International trade: The Position of Africa in Global Merchandise Trade. Emerging Issues in Economics and Development, Musa Jega Ibrahim, Intech Open. Retrieved from https://www.intechopen.com/books/emerging-issues-in-economicsand-development/international-trade-the-position-of-Africa-in-global-merchandisetrade.

Verter, N. (2017B). International trade: The Position of Africa in Global Merchandise Trade, Chapter 6 from the book: Emerging Issues in Economics and Development. Retrieved from http://www.intechopen.com/books/emergingissues-in-economics-anddevelopment.

Were, M. (2015). Differential effects of trade on economic growth and investment: A crosscountry empirical investigation.

World Bank (2019). World development indicators. Washington, D. C.

Zahonogo, P. (2016). Trade and economic growth in developing countries. Evidence from sub- Saharan Africa, Journal of African Trade, 3(1 - 2), 41 - 56.

\section{Copyrights}

Copyright for this article is retained by the author(s), with first publication rights granted to the journal. 
This is an open-access article distributed under the terms and conditions of the Creative Commons Attribution license (http://creativecommons.org/licenses/by/4.0/) 